\title{
Innovations in liver transplantation in 2020, position of the Belgian Liver Intestine Advisory Committee (BeLIAC)
}

\author{
G. Dahlqvist ${ }^{1,2}$, C. Moreno 3 , P. Starkel ${ }^{2}$, O. Detry ${ }^{4}$, L. Coubeau ${ }^{1}$, I. Jochmans ${ }^{5}$ on behalf of the BeLIAC \\ (1) Liver Transplant Unit; Cliniques Universitaires Saint-Luc, Brussels, Belgium ; (2) Hepatogastroenterology unit, Cliniques Universitaires Saint-Luc, Brussels, Belgium ; \\ (3) Liver Unit, Hopital Universitaire Erasme, Brussels, Belgium ; (4) Liver Transplant Unit, Hopital Universitaire du Sart Tilman, Liège, Belgium ; (5) Lab of Abdominal \\ Transplantation, Transplantation Research Group, Department of Microbiology, Immunology and Transplantation, KU Leuven, Leuven, Belgium.
}

\begin{abstract}
Liver transplantation (LT) remains the only curative option for patients suffering from end-stage liver disease, acute liver failure and selected hepatocellular carcinomas and access to the LT-waiting list is limited to certain strict indications. However, LT has shown survival advantages for patients in certain indications such as acute alcoholic hepatitis, hepatocellular carcinoma outside Milan criteria and colorectal cancer metastases. These newer indications increase the pressure in an already difficult context of organ shortage. Strategies to increase the transplantable organ pool are therefore needed. We will discuss here the use of HCV positive grafts as the use of normothermic isolated liver perfusion. Belgian Liver Intestine Advisory Committee (BeLIAC) from the Belgian Transplant Society (BTS) aims to guarantee the balance between the new indications and the available resources. (Acta gastroenterol. belg., 2021, 84, 347-359).
\end{abstract}

Key words: Liver transplantation, HCC, HCV, Alcoholic hepatitis, colorectal cancer metastasis, machine perfusion.

\section{Introduction}

Liver transplantation (LT) remains the only curative option for patients suffering from end-stage liver disease, acute liver failure and selected hepatocellular carcinomas and access to the LT-waiting list is limited to certain strict indications. However, recent studies have shown survival benefit with LT over conventional treatment for alcoholic hepatitis (AH) and hepatobiliary cancers (especially hepatocellular carcinoma, HCC) outside the current transplantation criteria and even for hepatic metastatic disease (especially colorectal metastasis), conditions that are currently not widely recognized as indications for LT (1,2,3-7). Such emerging new indications for LT are likely to put additional strain on an already challenged field suffering from donor organ shortage, emphasizing the importance of a balance between indications and resources. The Belgian Liver Intestine Advisory Committee (BeLIAC) of the Belgian Transplantation Society (BTS) aims to guarantee such a balance by critically reviewing LT emerging evidence on new LT indications as well as any efforts made on expanding the donor pool.

In this paper, we will discuss emerging indications for LT in AH, HCC, and colorectal liver metastases and then highlight two of the latest innovations to increase the donor pool, namely the effect of direct acting antivirals (DAA) on hepatitis C (HCV) $(6,7)$ and the use of HCV positive grafts as the use of normothermic isolated liver perfusion (NILP) as a platform to preserve, assess and resuscitate liver grafts trying to face organ scarcity.

\section{Emerging indications for liver transplantation}

\section{A. Liver transplantation for refractory alcoholic hepatitis}

Alcoholic liver disease is one of the most frequent indication for LT in Belgium and in the Western world. A six-month rule of abstinence is the usual requirement before a patient can be listed for LT for this indication and is driven by social and ethical considerations as well as avoidance of futile transplantations $(8,9)$. Refractory $\mathrm{AH}$ is not a classical indication for LT as the six-month abstinence rule does not apply. $\mathrm{AH}$ is a clinical syndrome corresponding to clinical, biological, and histological criteria. Clinically, it is characterized by recent onset of jaundice, with or without other signs of liver decompensation (i.e. ascites and/or encephalopathy), in patients with chronic alcohol abuse (10). Laboratory findings include hyperbilirubinemia ( $>3 \mathrm{mg}$ / $\mathrm{dL}$ ), serum levels of AST $>50 \mathrm{IU} / \mathrm{ml}$, although rarely above $300 \mathrm{IU} / \mathrm{ml}$, and an AST/ ALT ratio greater than 1.5 (11). Histologically, presence of steatosis, hepatocyte ballooning, and an inflammatory infiltrate with polymorphonuclear neutrophils are the criteria required for the diagnosis of $\mathrm{AH}$ (10). In its severe form, $\mathrm{AH}$ is characterized with mortality rates as high as $50 \%$ at 3 months without treatment and is the form of alcoholic liver disease that carries the poorest prognosis. Corticosteroids given orally ( $40 \mathrm{mg}$ prednisone for a maximum of 28 days) are the recommended therapy for severe forms of $\mathrm{AH}$. In a recent meta-analysis with individual participant data, patients treated with corticosteroids had a lower probability of death at 1 month compared to untreated patients (12). However, the benefit of corticosteroids is not sustained beyond 1 month. Moreover, the applicability of corticosteroid therapy is further restricted by concerns about the risk of sepsis. One major improvement in

Correspondence to: Geraldine Dahlqvist, Liver transplant unit, Cliniques Universitaires Saint-Luc, 10 avenue Hippocrate, 1200 Brussels, Belgium. Phone +327648306 .

Email : geraldine.dahlqvist@uclouvain.be

Submission date : 18/01/2021

Acceptance date : 30/01/2021 
the management of patients with severe $\mathrm{AH}$ in the last decade, is the possibility to early evaluate response to therapy. The Lille model, which is based on pretreatment liver function parameters plus the evolution of bilirubin serum levels at day seven of a course of corticosteroid therapy was developed. This score ranges from 0 to 1 ; a score $\geq 0.45$ indicates non-response to corticosteroids and is associated with a very high risk of six-month mortality (ranging from 70 to $80 \%$ ) (13). As corticosteroids allow only a modest improvement in prognosis and because there is currently no other therapeutic option for nonresponders to corticosteroids, LT could be lifesaving and has been proposed in highly selected patients. In 2005, a French consensus conference recommended pilot studies to evaluate early LT in carefully selected patients with severe AH and non-responder to medical therapy (14).

Current available data on liver transplantation for refractory $\mathrm{AH}$

Several studies have demonstrated the benefit of LT on the prognosis of selected patients suffering from severe/ refractory $\mathrm{AH}$. In the first French-Belgian landmark study, 26 patients with severe $\mathrm{AH}$ not responding to medical therapy were selected using a strict selection process and underwent a LT within a median of 13 days after nonresponse to medical therapy (1). As expected, 6-month and 2-year survival rates of transplanted patients were better than that of non-transplanted matched nonresponders: $77 \%$ vs. $23 \%$ at 6 months and $71 \%$ vs. $23 \%$ at 2 years, respectively. Alcohol relapse after LT occurred in 3 patients after 720 days, 740 days and 1140 days. One patient had harmful drinking while the 2 others were occasional drinkers. There was no graft loss related to alcohol relapse during the follow-up period.

Then, experiences of LT for AH coming from the United States (US) were published and confirmed the benefit in terms of survival in non-responders to medical therapy, with an acceptable rate of alcohol relapse after LT. Data on outcomes after LT in patients with AH were then synthetized in a meta-analysis (15). This metaanalysis included studies in which patients with recent jaundice and severe $\mathrm{AH}$ were transplanted, as well as studies in which $\mathrm{AH}$ was discovered on the explant. The overall 6-month survival rate was $85 \%$ and was similar to that of patients transplanted for alcoholic cirrhosis. Fourteen percent of patients had alcohol relapse in the subgroup analysis including only studies of patients transplanted for severe $\mathrm{AH}$ that used stringent criteria for selecting candidates. This rate of alcohol relapse after LT was similar to that of patients with alcoholic cirrhosis who underwent LT after a sobriety period of at least 6 months.

More recently, the results of a large multicenter observational US study were published (ACCELERATEAH) (16). This study included 147 patients with severe $\mathrm{AH}$ without a prior diagnosis of liver disease who underwent LT before 6 months of abstinence from
2006 to 2017 in 12 centers. The survival rate of the 141 transplanted patients was excellent (94\% at one year and $84 \%$ at 3 years). Alcohol relapse occurred in 40 liver transplant recipients $(28 \%)$, with a minority of patients drinking harmfully $(11 \%)$. The only factor associated with alcohol relapse after transplantation in multivariable analysis was younger age.

The first prospective study evaluating early liver transplantation (eLT) in patients with severe $\mathrm{AH}$ not responding to medical therapy (the French-Belgian QUICKTRANS study) was presented in an abstract form at the last Liver Meeting (17). The primary aims of this study was to compare 2-year alcohol relapse and survival between patients with severe AH selected and transplanted for eLT (68 patients), and patients transplanted for alcohol-related cirrhosis with at least 6 months of abstinence (93 patients). Two-year alcohol relapse was $33,8 \%$ in patients receiving eLT for severe $\mathrm{AH}$ and $24,7 \%$ in patients transplanted for alcoholrelated cirrhosis (non-inferiority hypothesis between the 2 groups not demonstrated). Two-year survival was similar between both groups $(89,7 \%$ and $88,1 \%$ in eLT group and alcohol-related cirrhosis group, respectively).

Ethical considerations surrounding the use of LT in AH patients

Considering early LT for patients with refractory AH has raised the problem of equity in liver graft allocation in the specific setting of alcoholic liver disease $(18,19)$. Several lines of arguments are often put forward to refuse patients with AH for LT. Most common reasons are : (i) hope that liver function will improve after alcohol withdrawal which would make LT unnecessary; (ii) fear that alcohol relapse could have a negative impact on prognosis which would make liver transplant, if not useless, at least of limited utility; (iii) fear that considering LT in patients with a self-inflicted disease could raise a problem of equity in liver graft allocation and in both public opinion and healthcare providers who participate in candidate selection which could reduce the number of potential donors; and finally (iv) organ shortages.

The possibility to offer an early liver transplant to these patients challenges the traditional 6-month rule of abstinence. While the positive effect of alcohol abstinence on liver function is well established in patients with alcoholic liver disease, this effect takes at least 3 months to be significant. As most non-responders to corticosteroids died within 3 months after the onset of the disease, this option is not conceivable for patients with refractory $\mathrm{AH}$. Hence, new criteria to select patients with refractory $\mathrm{AH}$ who are at low risk of alcohol relapse after LT that should not be based on the duration of abstinence are needed.

Health-care providers are afraid of considering LT in $\mathrm{AH}$ patients for a potential higher risk of alcohol relapse after LT, due to the absence of a significant period of abstinence before LT. Although long-term data are still 
needed, some recent reports indicate that only few patients with refractory AH who underwent early LT returned to alcohol consumption after transplantation, and the risk of alcohol relapse in those patients does not appear to be higher compared to patients transplanted for alcoholrelated cirrhosis and a period of abstinence of more than 6 months before LT. This favorable result is likely related to the fact that studies that assessed this issue applied a very strict selection process to select candidates. Therefore, the rate of alcohol relapse probably depends on the mode of assessment before LT. Several criteria were proposed to select candidate before to be considering for LT: the patient must present his/her first liver decompensation event, should have a strong family support, should not present psychiatric disorders and should adhere to lifelong alcohol abstinence programs. When applying these criteria, only $14 \%$ of $\mathrm{AH}$ transplanted patients for severe/refractory $\mathrm{AH}$ had recurrent alcohol intake after LT (15). However, this selection process is still imperfect and needs to be refined. For example, the criterion of a first liver-decompensating event as a prerequisite to select candidates may be considered as unfairly discriminative as some patients in whom $\mathrm{AH}$ is not the first decompensation event may present other favorable prognostic factors of future abstinence. In line with this, the identification of factors associated with alcohol relapse in the recently presented French-Belgian QUICKTRANS study will be of high interest to help transplant teams to select early LT candidates in daily practice (17).

One common moral judgement against $\mathrm{AH}$ patients is that $\mathrm{AH}$ is a self-inflected disease. This argument is discriminating when considering the principles of beneficence, non-maleficence, equity and justice that are essential in human care. In addition, $\mathrm{AH}$ results from a combination of many factors that includes individual predisposition, a point largely supported by the observation that a minority of excessive drinkers suffer from AH. Thus, AH patients cannot be considered as entirely responsible for their disease and refuting LT in these patients could be seen as a second punishment after the occurrence of AH. Moreover, clinicians and the public opinion are used to consider LT for other self-induced diseases such as suicide related acetaminophen-induced liver failure or obesity-induced cirrhosis without raising any ethical issue in graft allocation. Thus, the notion of merit to be treated is against all ethical principles in medicine and it should not, in it-self, be considered as an obstacle to have access to any treatment.

Lastly, the impact of refractory $\mathrm{AH}$ as a new indication for LT on LT activity may be viewed as a limitation. However, if we consider that, among $38 \%$ of nonresponders to corticosteroids, less than $10 \%$ are eligible for LT when a strict selection process is applied (a percentage observed in the Mathurin's study), then only $3 \%$ of all patients with severe $\mathrm{AH}$ would be candidates for LT. In a country as Belgium in which we assume that approximately 120 patients with severe $\mathrm{AH}$ are diagnosed every year, 4 of them would be candidates for LT, a number that should not impact that much liver transplant activity.

In conclusion, there is sufficient evidence to support the fact that LT is life-saving in selected severe $A H$ patients. BeLIAC have therefore decided that in these selected patients eLT could be performed in Belgium. Equity should be respected in the setting of AH as in other conditions in which LT is discussed. In the future, optimization and harmonization of the selection criteria between centers are needed. We also need tools to predict alcohol relapse after LT and improve management of alcohol use disorder after LT.

\section{B. BeLIAC, Hepatocellular carcinoma and FDG-PET- CT}

In recent years, a new concept named transplant oncology has emerged, opening new therapeutic options in the treatment of cancers involving the liver (4). Hepatobiliary cancers have been the first indications for LT but were rapidly abandoned because of dismal oncological results until better characterization of the optimal recipients.

In Belgium and the other Western countries, HCC complicating cirrhosis has become one of the leading indications for LT and a major research interest for BeLIAC (20,21). As there is a lack of deceased liver donors, the liver allocation system of many countries has included a tight selection of the HCC patients who may benefit the most from LT, with the lowest risk of recurrence. For years, this risk of HCC recurrence was related only to the size and the numbers of the HCC nodules, following the so-called "Milan Criteria" $(22,23)$. As such, in the actual Eurotransplant patientoriented graft allocation, patients suffering from HCC complicating cirrhosis receive "standard exception" (SE) points to allow LT in a timely manner, if HCC is limited to one nodule not exceeding $5 \mathrm{~cm}$ of diameter, or three nodules not exceeding $3 \mathrm{~cm}$ (4). However, it is clear that, if size and number matter, the biology of the HCC itself is also of great importance. Some centres have been using extended LT criteria for HCC and reported good results, confirming that the criteria based only on size and number might be too tight and that some HCC patients might be wrongly excluded from LT by the Milan criteria (22). The Milan group more recently proposed the "upto-seven criteria" with 7 being the sum of the size of the largest tumor in $\mathrm{cm}$ and the number of tumours, achieving a 5-year overall survival of 70\% (24).

Beside size and number of nodules, the HCC aggressiveness might be evaluated by tumor differentiation and by the presence of microvascular invasion at biopsy. However, HCC biopsy might be difficult in cirrhotic patients. In addition, biopsy is not always reliable, particularly in multinodular $\mathrm{HCC}$, and differentiation of one nodule is not always consistent in the whole tumoral mass. Due to these pitfalls, HCC biopsy is not 
used for deceased liver allocation, but for diagnosis. Alfa-fetoprotein (AFP) is also a surrogate marker of HCC differentiation and was associated to microvascular invasion, increased recurrence rate, and reduced survival after LT (24). In France, Duvoux et al. developed a prognostic model, that combines AFP level and HCC tumor size and number, with different cut-offs for each variable for predicting recurrence after LT (3). This model allowed better selection of HCC patients with low or high risk of recurrence, compared to the Milan criteria, and has been adopted into the official liver allocation policy in France since 2013.

Recently, captation of 18F-fluorodeoxyglucose (FDG) at positron emission tomography (PET) has been proposed to evaluate HCC biology. FDG-PET/CT is now considered in the staging of HCC patients prior to listing for LT and is covered by the Belgian social security system in this indication. The interest of FDGPET was pointed out in a recent important retrospective study showing that negative PET/CT was an independent clinical predictor of DFS in patients within up-to-seven criteria (25). The LT group of the University Hospital of Liege published its retrospective series showing FDG$\mathrm{PET} / \mathrm{CT}$ with an RSUVmax cut-off value of 1.15 as a strong prognostic indicator. Interestingly in this series, the risk of recurrence did not differ in HCC Milan-out/ FDG-PET negative patients when compared to HCC Milan-in/FDG-PET negative patients (26). This finding confirmed other retrospective mono-centric studies (27).

To confirm these preliminary data, Be-LIAC recently initiated a prospective study evaluating LT indication in patients with PET/CT negative HCC outside Milan criteria, but inside the up-to-seven criteria. This original, prospective and multicentre study, including the 6 Belgian LT centres, might have a major impact on selection of HCC LT candidates and might offer hope for curative management for these patients.

\section{Liver Transplantation for colorectal cancer liver metastases}

Colorectal cancer (CRC) is the third most frequently diagnosed cancer in men and the second in women with more than one million eight hundred thousand new cases and almost 850,000 deaths per year worldwide (WHO). The incidence and mortality of CRC vary considerably from country to countr y $(28,29)$ and the condition affects increasingly younger patients (29). Liver metastases (CRMets) are present in $15-20 \%$ of patients at the time of diagnosis and $20-25 \%$ of non-metastatic patients will develop CRMets within three years of their primary colonic tumor surgery $(30,31)$. Liver surgery remains the cornerstone of the management of these patients, but less than $25 \%$ of them are immediately resectable (32). The response to current chemotherapies has significantly increased resectability by decreasing hepatic tumor volume. However, the situation remains worrying for patients who remain inoperable: average survival of 2 years from the first line of chemotherapy and overall survival at 5 years of less than $10 \%(32-35)$. Furthermore, these figures do not seem to be improved by the combination of chemotherapy with loco-regional ablative techniques such as radioembolization (36).

In this background of poor prognosis in patients with isolated liver disease, the option of total hepatectomy has long been discussed. The first historical results of LT in CRMets are very questionable (between 12 and $21 \%$ 5 -year survival (37). They reflect a surgical reality of the time and especially a lower quality in the selection of recipients. Almost 93 cases are reported before 2000.

A new era has been initiated in Norway with the SECA I study (2006-2011) : 21 patients are selected on the basis of unresectable limited hepatic disease associated with stability within a minimum of 6 weeks of chemotherapy (6). The extremely encouraging results $(60 \%$ survival at 5 years) reignite the debate, compared with the same cohort of the best respondents to chemotherapy alone associated with targeted therapy (NORDIC VII study: $8.5 \%$ survival at 5 years ) (38). The gain in survival was considerable (more than 50\%). This potential benefit is further improved by the definition in 2018 of the Oslo criteria (39) : diameter of the largest metastasis less than $55 \mathrm{~mm}$, CEA value before transplantation less than $80 \mathrm{ng}$ $/ \mathrm{ml}$ and stability of the disease under chemotherapy for more than 24 months. The combination of these different criteria allows these highly selected patients a survival of around $83 \%$ at 5 years $(40,41)$.

These results are nevertheless limited by the context of organ shortage, but they reopen the debate in a context where the considerable expansion of imaging techniques and high throughput sequencing of tumor DNA allow us to improve the evaluation of patients with colorectal cancer. At the same time, new systemic treatments have increased our ability to obtain tumor control.

Inspired by the Norwegian experience and driven by these evolving elements, Professor René Adam from the Paul-Brousse hospital in Paris, a pioneer in hepatobiliary surgery, has initiated a new protocol for the randomized evaluation of $L T$ in colorectal metastases: palliative chemotherapy alone versus chemotherapy and liver transplant. The validation of this clinical research protocol at the French national level prioritizes the patients selected from the waiting list. After approval by the BeLIAC, all Belgian liver transplant centers have been participating in this protocol since the end of 2017. The selection criteria remain, however, and rightly so, requiring the approval of an international college of experts.

There are therefore currently 7 study protocols evaluating the transplant in the irresectable CR-Mets (iCRMets) and registered on ClinicalTrials.gov (42):

Liver transplant from cadaveric donors.

1. TRANSMET (NCT02597348) : Opened in 2015, the French multicenter protocol evaluates the 
curative potential of LT for iCRMets as part of a 1:1 randomized protocol: chemotherapy alone vs transplant plus chemotherapy. Patients allocated to the LT arm benefit from a bonus on the Eurotransplant waiting list.

The protocol is accessible to Belgian and Italian patients since the end of 2018. The first belgian patient has been transplanted in March 2019 with to date 6 randomized patients from 2 belgian centers. However, difficulties emerge from the randomization and scientific ethics of leaving patients in the chemotherapy arm after inclusion in contexts of "borderline" resectability. We know in these patients that even more marginal resection (vascular R1) increases survival (43)

Another pitfall in this study is organ shortage and secondary mortality on the waiting list. The protocol access criteria are also extremely strict and discussed for each patient within a group of international experts. Paradoxically, the approval of files for this consortium is made more difficult in patients with a prolonged oncological history, yet a guarantee of stability and a better prognosis.

2 SECA II (NCT01479608) : This Norwegian protocol, an extension of the original SECA study, opened in 2011 for 25 patients. The selection criteria are based on those of Oslo: stability of 12 months after resection of the primary tumor and CEA less than $100 \mathrm{ng} / \mathrm{mL}$ at the time of diagnosis. The randomized phase 3 protocol targets patients with a minimum of 6 resectable liver lesions, allocating them 1:1 to either liver resection or transplantation.

3 SECA III (NCT03494946) : Modeled on the SECA II protocol and started by the same Scandinavian team in 2016, this protocol evaluates, according to the same principle, for patients deemed to be unbreakable from the outset, the transplant versus chemotherapy, radioembolization, intravenous chemotherapy. - arterial, stereotaxic or other radiotherapy. The randomized phase III protocol is currently recruiting 30 patients.

Liver Transplant from living donation Adult-to-adult LDLT or RAPID procedure: Since patients with CLM as a rule of thumb have normal liver function and no portal hypertension, their demands towards optimal graft quality are lower than cirrhotic patients. Hence, the donor pool could be expanded through extended criteria donor and partial liver graft (split and living donor).

4 A Canadian protocol open since 2016 (NCT 02864485) : Single-center non-randomized living donor transplant evaluation for iCRMets. The control group under chemotherapy alone is made up of patients excluded for a reason other than the pejorative oncological evolution (absence of donor, extra-oncological contraindication to the transplant). The Toronto team varies in the use of left to right grafts depending on volumetric considerations. Unfortunately, donor safety and small-for-size grafts remain an unresolved problem that have even led to dual LDLT, with questionable ethics and technical drawbacks. Five years ago, Line et al. described the RAPID concept with discarded split left lateral lobe a novel technique of two-step total hepatectomy for CRLM associating left-liver resection with partial orthotopic LT (POLT) and delayed right hemihepatectomy (44). This novel two-stage strategy eases ethic debates around LDLT. The risk of liver failure in donors is reduced after left hepatectomy. Likewise, residual native liver shelters recipients from possible temporary graft shortfall. This ground-breaking ruse gives small grafts time to regenerate, while residual native liver act as a stake, which supports metabolic functions and prevents emergency listing of patients whose primary indication was controversial. LD-RAPID concept may be a logical consequence of the RAPID strategy (45) and an innovative and potentially paradigmchanging concept in the treatment of patients with unresectable CLM. One major point is the ethical justification for such a procedure, that is, putting a living donor at risk for the treatment of another person.

5 RAPID (NCT02215889): After the casuistic success of the RAPID technique, the Norwegian group is setting up a phase 1-2 protocol evaluating in 20 patients the auxiliary graft technique with 2-stage hepatectomy from bi-segments of cadaveric donors.

6 Liver $T(W)$ O Heal (NCT03488953): Combining the technical innovation of Oslo and living donor transplantation, the Tubingen team publishes the use of a left mini-graft from living donor, implanted orthotopically after left hepatectomy in the recipient using the RAPID technique. They perform the complete hepatectomy of the right liver 2 weeks after the transplant. This Living Donor RAPID (LDRAPID) was described by Nadalin's team in 2018 (46) and the technique being validated by an open protocol in 201912. In May 2019, 3 of the 40 patients had already been included and transplanted using this technique. The selection criteria are unresectable hepatic status and tumor stability or regression over 8 weeks of chemotherapy. The first step associates grafting with colectomy for synchronous diseases; there is therefore no evaluation of the prognosis on criteria linked to the primary lesion (pTNM, margins). Unlike the above studies, the authors do not exclude patients with resectable lung metastases.

7 ALDAPT protocol (Associating Living Donor Left APOLT and Right Portal vein ligation for Total Staged Hepatectomy). This auxiliary transplant protocol with a two-stage hepatectomy is open since May 2020 in Brussels (47). It is open to patients with iCRMets but also to patients with neuroendocrine tumor metastasis and hepatocellular cancer on wellcompensated cirrhosis. Owing to the longstanding experience already acquired with LDLT for children, 
the safety of the living donor was never a matter of major concern. The results of the Cliniques universitaires Saint Luc including 438 living left liver donors for pediatric recipients confirm in 2020 the absence of mortality and / or major complications and less than $18 \%$ of minor complications (48).

The original Norwegian SECA study sees the majority of patients with recurrent lung tumors. An analysis of the growth rates of these metastases has recently been compared with those of metachronous lung lesions in non-transplant patients (49). Growth does not seem to be influenced by the immunosuppressive background. At the same time, the overall survival at 5 years after pulmonary resection in these transplant patients remains satisfactory (51\%) and can be superimposed on that of patients without a transplant context. These data allow us to consider patients with resectable lung disease for LT. The stability of the disease remains, however, an essential criterion in the selection of candidates and particularly in the pulmonary metastatic context.

Most of the centers investigating TRH in iCRMets are orienting their anti-rejection regimen towards classic tri-therapy combining CNI, corticosteroids and antimetabolites. An mTor inhibitor is added empirically for its potential anti-oncogenic effect (50). The doses administered are however much lower than those demonstrating this effect. It is extremely difficult to assess the potential effect of immunosuppression on the course of established colorectal cancer. However, the incidence of colorectal cancer in solid organ transplant patients is identical to that of the general population (excluding TRH for sclerosing cholangitis associated with IBD) $(51,52)$.

These elements associated with the published data on pulmonary metastases of SECA I lead us to consider immunosuppression as monotherapy. The immunosuppression protocol of SECA I consisted of induction with basiliximab, sirolimus (mTOR inhibitor) or tacrolimus the first four to six weeks then conversion to sirolimus (SECA-II study).

This new step in the development of transplantation oncology is conditioned by patient selection criteria: the application of strict criteria reduces the risk of recurrence after transplantation. Thus the combination of pre transplant Fong Clinical Risk Score (node positive primary, interval from primary to diagnosis of CRMets $<12$ months, $>1$ liver metastasis, preoperative CEA level $>200 \mathrm{ng} / \mathrm{ml}$, size of the largest lesion $>5.0 \mathrm{~cm}$ ), Oslo Score and a low metabolic tumour volume at $18 \mathrm{~F}-\mathrm{FDG}$ PET scan allows a 5-year overall survival up to 100 (40). The question then arises as to whether the application of overly strict criteria, which would nonetheless benefit from a significant potential gain in survival, should lead to the rejection of candidates (53).

LT for iCRMets therefore represents real hope for patients otherwise doomed in the short term. Recent results are directly conditioned by the selection criteria.
Ultra-selected patients have better survival and diseasefree survival than patients transplanted for hepatocellular cancer Milan IN who benefit from standard waiting list exceptions. However, the current mortality in the cadaveric waiting list will not allow us to absorb these new potential candidates. The option of living donation should therefore be considered, but with all the ethical issues of donation in the context of a debated oncological indication. The principle of sequential total hepatotomy associated with an auxiliary transplant then takes on its full meaning: it applies a minimization and standardization of risk taking in the donor as well as protection of the recipient by preserving a hepatic metabolic reserve in the initial phase of the transplant.

\section{Emerging strategies to increase the donor organ pool}

A. Transplanting organs from $\mathrm{HCV}$-positive donors into $\mathrm{HCV}$-negative recipients in the direct acting anti-virals era: a changing landscape

The landscape of HCV has profoundly changed with introduction of direct acting antivirals. Cure rates are exceptionally high with an excellent safety profile and treatment durations may be as short as 8 weeks with powerful pangenotypic combinations. To date, organs from $\mathrm{HCV}+$ donors are only exceptionally used for transplantation and generally directed to $\mathrm{HCV}+$ recipients. However, transplant programs are facing a rising demand for liver transplants and time on the waiting list increases constantly. Therefore, the use of $\mathrm{HCV}+$ donors could represent a new opportunity to expand the donor pool in the DAA era (54).

Nevertheless, one might still face an ethical problem especially with the use of nucleic acid testing (NAT) positive organs. The Hippocratic oath taken by every doctor implies that our main consideration should be "first do no harm". Therefore, the use of HCV-NAT+ organs for an $\mathrm{HCV}$-negative recipient might be considered as a detrimental act. High, almost universal HCV infection or recurrence in the HCV-negative recipient is the rule, which means that we are transplanting also a new disease together with organ if no effective prophylaxis and/or treatment is available. But this is precisely where the new DAA regimens change the rules of the game.

The impact of HCV on graft and patient survival in organ transplantation

\section{The liver as a bystander}

In non-liver organ transplantation, the liver is usually a bystander that suffers the consequences of the viral assault. If untreated, patients can develop a severe form of hepatitis $\mathrm{C}$ known as fibrosing cholestatic hepatitis or might suffer from accelerated fibrosis progression that impact their quality of life and even survival. 
$\mathrm{HCV}$ infection might also have a detrimental effect on the transplanted organ itself as, for instance, in kidney transplantation (55-57). It is common practice to discard $\mathrm{HCV}$-infected subjects from organ donation and consequently HCV-infected organs are currently being largely underutilized to increase the pool of organs available for transplantation.

\section{The liver as a transplanted organ}

Early studies found little evidence that either shortterm graft or patient survival was affected by transplanting $\mathrm{HCV}+$ grafts instead of $\mathrm{HCV}$ negative (HCV)) grafts into $\mathrm{HCV}+$ patients. It was concluded that similar graft survival and equivalent if not increased patient survival rates were evident in the $\mathrm{HCV}+$ donor compared with the $\mathrm{HCV}$ - donor for $\mathrm{HCV}+$ recipients. This observation also seems to hold true in the relatively rare situations where $\mathrm{NAT}+$ grafts have been transplanted into $\mathrm{HCV}$ - recipients in the pre-DAA era (58-60). Recent studies confirmed this trend with excellent short- and medium-term graft and patient survival (61-63).

Even if one admits that the benefit-harm balance might not be $100 \%$ neutral when $\mathrm{HCV}+$ grafts are used for $\mathrm{HCV}$ - recipients, we should not forget that the transplant community already allows exceptions to this principal of a neutral balance. We are using grafts from donors at high risk of transmitting viral infections as for instance in CMV or EBV donor/recipient mismatch or the use of hepatitis B core antibody-positive donor grafts. Although not $100 \%$ efficacious, prophylactic strategies exist for preventing $\mathrm{CMV}$ and $\mathrm{HBV}$ infection in the recipient. Therefore, the use of expanded criteria donors and the related risks for the recipient, e.g. the risk of increased rejection, development of CMV disease, HBV-related hepatitis or even EBV-related post-transplant lymphoproliferative disease, is generally considered acceptable (64).

\section{Definition of an $\mathrm{HCV}+$ donor}

Classically, HCV serology testing is used for HCV screening. However, this strategy might not be optimal in organ transplantation for several reasons. A positive HCV serology does not automatically mean infectivity. Studies have shown that $\mathrm{HCV}$ transmission to the recipient is low (less than $10 \%$ in some series) if the donor is HCV NAT- which suggests that many HCV antibody+ but NAT- organs are being discarded without a clear scientific rational behind (65-69). The window period between infection and HCV antibody development can be as long as 2 months which is extremely relevant if one considers the use of potential high-risk donors as defined by the CDC guidelines (70). In addition, immunocompromised individuals do not necessarily have antibody seroconversion in the setting of $\mathrm{HCV}$ viremia as recently highlighted in recipients of HCV-infected kidneys (71). The use of HCV nuclear acid testing (NAT)

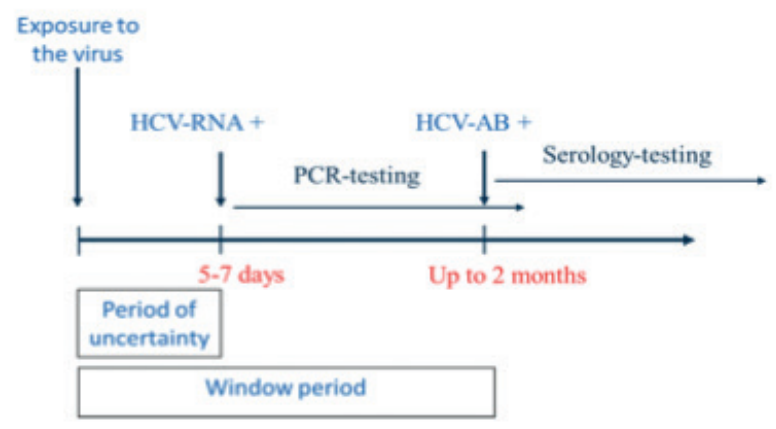

Figure 1. - Time course for the development of HCV-RNA (nucleic acid testing) and HCV antibody (serologic testing) positivity after exposure to the virus

can reduce the window period to 5 to 7 days although is does not completely eliminate the risk of missing active $\mathrm{HCV}$-infection in a subject with very recent exposure to the virus (Fig 1.). Nevertheless, determination of $\mathrm{HCV}$ viremia but not $\mathrm{HCV}$ serology should be the gold-standard not only for assessment of donors but also for followup of recipients of $\mathrm{HCV}$-infected organs. Consequently, a true $\mathrm{HCV}$-positive donor is in general both HCV-Ab positive and NAT-positive. Testing for HCV-antibodies alone is insufficient whereas a negative serological test but positive NAT ascertains $\mathrm{HCV}$-infectivity and high risk of transmission. Finally, careful evaluation of HCVpositive donor livers for fibrosis prior to transplantation is highly recommended since livers with advanced fibrosis on histology should be discarded. This implies that predonation liver biopsies might be necessary especially for donors beyond 35 years of age who are more likely to have chronic infection and greater risk for having advanced hepatic fibrosis.

Current experience in treating/preventing HCV infection in HCV-negative solid organ recipients transplanted with an HCV-positive graft.

Acceptance rates of $\mathrm{HCV}+$ organs by patients and doctors in the DAA era are constantly increasing and more and more centers were considering using an $\mathrm{HCV}$-positive donor liver grafts in hepatitis C-negative recipients. A recent survey revealed that many recipients had a positive perception toward the use of HCV-viremic organs and would accept such an organ if comprehensive HCV-related pre-transplant education is provided (72).

Two strategies are currently employed for patients who have received a transplant from an HCV-NAT+ donor. The first one consists of a preemptive approach advocating the start of DAAs as soon as possible (within the first hours/day) after transplantation without waiting for a positive PCR test. This strategy would be difficult to implement in Belgium given the reimbursement rules for treatment and PCR testing in force.

The second strategy is a monitor and treat approach that requires regular and frequent HCV-PCR testing. 


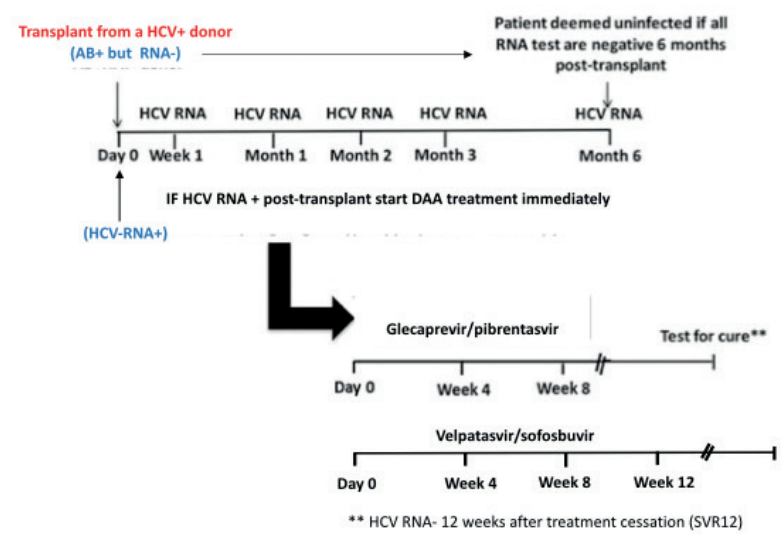

Figure 2. - Algorithm for a monitor and treat strategy after transplantation of either an HCV RNA+ or an HCV antibody (AB) but RNA- donor organ. DAA denotes direct acting antivirals and SVR sustained virological response.
Treatment is immediately started if at any time posttransplant HCV-RNA is detected (Fig. 2). This approach also could be of particular interest in patients who received an organ from an $\mathrm{HCV}$-antibody positive but NAT-negative donor since, as mentioned above, only a minority of those recipients will become viremic after transplantation. In addition, it seems reasonable to stop PCR monitoring beyond 6 months if all previous tests returned negative and the patient is deemed uninfected.

Table 1 summarizes the currently published real-world data concerning the use of $\mathrm{HCV}$ positive donor organs in $\mathrm{HCV}$ negative recipients, their concurrent DAA treatment and success rates. Overall, treatment response rates were excellent with sustained virological response (SVR) rates largely exceeding $90 \%$, similar to those obtained in nontransplant $\mathrm{HCV}$-infected patients. No particular safety signals have emerged in the transplant recipients in this real-world experience (66,73-89).

Table 1. - Real-world data of HCV-positive organs transplanted into HCV- negative recipients (66,73-89)

\begin{tabular}{|c|c|c|c|c|c|}
\hline & Organ & $\begin{array}{c}\mathrm{N}^{\circ} \text { of recipients HCV- } \\
\text { RNA + }\end{array}$ & HCV genotype & DAA therapy & SVR12 \\
\hline Bari et al. 2018 & liver & 4 & $1 \mathrm{a}, 3$ & $\begin{array}{l}\mathrm{LED} / \mathrm{SOF} \pm \mathrm{Rib} \\
\mathrm{VEL} / \mathrm{SOF}\end{array}$ & $\begin{array}{c}100 \% \\
\text { (1 untreated) }\end{array}$ \\
\hline Campos-Varela et al. 2018 & liver & 1 & 3 & $\mathrm{LED} / \mathrm{DAC} \pm \mathrm{Rib}$ & $100 \%$ \\
\hline Kwong et al. 2019 & liver & 10 & $1 \mathrm{a}, \mathrm{b}, 2 \mathrm{~b}, 3$ & $\begin{array}{l}\text { LED/SOF } \pm \text { Rib } \\
\text { VEL/SOF } \pm \text { Rib } \\
\text { DAC/SOF/Rib }\end{array}$ & $100 \%$ \\
\hline Bethea et al. 2020 & liver & 10 & NA & GLE/PIB & $100 \%$ \\
\hline Bohorquez et al. 2020 & liver & 56 & $1 \mathrm{a}, 1 \mathrm{~b}, 2,3$ & $\begin{array}{l}\text { GLE/PIB } \\
\text { VEL/SOF }\end{array}$ & $\begin{array}{l}51 \text { SVR (1 relapse with SVR after } \\
\text { second-line treatment), } 5 \text { ongoing }\end{array}$ \\
\hline Said et al. 2020 & liver & 8 & $1 \mathrm{a}, 1 \mathrm{~b}, 2,3$ & $\begin{array}{l}\text { GLE/PIB } \\
\text { VEL/SOF }\end{array}$ & $\begin{array}{c}89 \% \\
1 \text { death not HCV-related }\end{array}$ \\
\hline Shah et al. 2017 & $\begin{array}{l}\text { Liver } \\
\text { Kidney }\end{array}$ & $\begin{array}{l}1 \\
2 \\
\end{array}$ & 1a & $\mathrm{LED} / \mathrm{SOF} \pm \mathrm{Rib}$ & $100 \%$ \\
\hline Crismale et al. 2020 & $\begin{array}{l}\text { Liver (kidney) } \\
\text { kidney }\end{array}$ & $\begin{array}{l}13 \\
13\end{array}$ & $1 \mathrm{a}, 1 \mathrm{~b}, 3$ & $\begin{array}{l}\text { GLE/PIB } \\
\text { SOF/? }\end{array}$ & $\begin{array}{l}92 \% \text { (1 death non HCV-related) } \\
8 \text { SVR, } 5 \text { ongoing }\end{array}$ \\
\hline Kapila et al. 2020 & $\begin{array}{l}\text { Liver(kidney) } \\
\text { Kidney } \\
\text { Heart (kidney) }\end{array}$ & $\begin{array}{c}6 \\
58 \\
7\end{array}$ & $\begin{array}{c}1 \mathrm{a}, 3,4 \\
1,2,3,4 \\
1 \mathrm{a}, 2\end{array}$ & $\begin{array}{c}\text { GLE/PIB } \\
\text { LED/SOF, GLE/PIB, } \\
\text { LED/SOF, GLE/PIB }\end{array}$ & $\begin{array}{l}\text { 3 SVR, 1ETR, } 2 \text { ongoing } \\
41 \text { SVR, } 10 \text { ETR, } 7 \text { ongoing } \\
6 \text { SVR, } 1 \text { ongoing }\end{array}$ \\
\hline Franco et al. 2019 & Kidney & 4 & $1 \mathrm{a}$ & GLE/PIB & $100 \%$ \\
\hline Durand et al. 2018 & Kidney & 10 & $1 \mathrm{a}, 2,3$ & $\begin{array}{l}\text { GZR/EBR GZR/EBR/ } \\
\text { SOF }\end{array}$ & $100 \%$ \\
\hline Reese et al. 2018 & Kidney & 20 & 1a & GZR/EBR & $100 \%$ \\
\hline Wettersten et al. 2019 & Heart/kidney & 1 & $1 \mathrm{a}$ & GZR/EBR & $100 \%$ \\
\hline McLean et al. 2019 & Heart & 10 & 1 & GZR/EBR & $\begin{array}{c}90 \% \\
\text { (1 death non HCV-related) }\end{array}$ \\
\hline Bethea et al. 2019 & Heart & 20 & NA & GLE/PIB & $100 \%$ \\
\hline Moayedi et al. 2018 & Heart & 2 & 1a & $\begin{array}{l}\mathrm{LED} / \mathrm{SOF} \\
\mathrm{VEL} / \mathrm{SOF}\end{array}$ & $100 \%$ \\
\hline Schlendorf et al. 2018 & Heart & 9 & NA & NA & $\begin{array}{c}90 \% \\
\text { (1 death non HCV-related) }\end{array}$ \\
\hline Zhu et al. 2020 & Heart & 3 & 1a & $\begin{array}{l}\text { LED/SOF, VEL/SOF, } \\
\text { GLE/PIB }\end{array}$ & $100 \%$ \\
\hline Woolley et al. 2019 & $\begin{array}{l}\text { Heart } \\
\text { Lung }\end{array}$ & $\begin{array}{c}7 \\
28\end{array}$ & $1,2,3$ & VEL/SOF & $100 \%$ \\
\hline Smith et al. 2020 & $\begin{array}{l}\text { Heart } \\
\text { Lung }\end{array}$ & $\begin{array}{l}22 \\
16\end{array}$ & $1 \mathrm{a}, \mathrm{b}, 2,3$ & GLE/PIB & $100 \%$ \\
\hline Cypel et al. 2019 & Lung & 22 & NA & VEL/SOF & $\begin{array}{c}91 \% \text { (2 relapses; } 1 \text { death non } \\
\text { HCV-related) }\end{array}$ \\
\hline
\end{tabular}

DAA, direct-acting antivirals ; LED, ledipasvir ; SOF, sofosbuvir ; VEL, velpatasvir ; DAC, daclatasvir ; GLE, glecaprevir ; PIB, pibrentasvir ; GZR, grazoprevir ; EBR, elbasvir, Rib, ribavirin ; SVR, sustained virological response ; HCV, hepatitis C virus ; NAT, nucleic acid testing. 
Table 2. - DAA regimens and drug interactions with immunosuppressive medication

\begin{tabular}{|c|c|c|c|c|c|c|}
\hline & 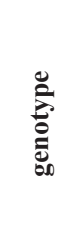 & 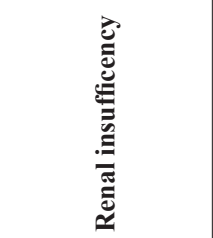 & 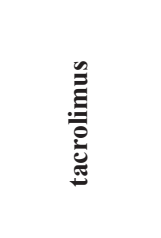 & 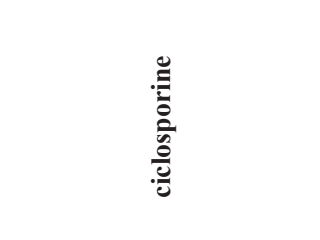 & 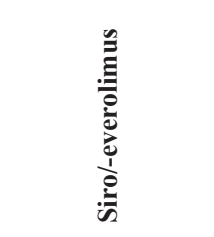 & 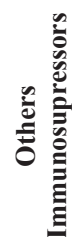 \\
\hline Glecaprevir/ pibrentasvir (Maviret $\AA$ ) & pan & ok & Tacro $(1,5 \mathrm{x})$ & Avoid if possible (Maviret) & Slight Siro/evero & ok \\
\hline Sofosbuvir/ velpatasvir (Epclusa $\left.{ }^{\circledR}\right)$ & pan & GFR $>35 \mathrm{ml} / \mathrm{min}$ & ok & ok & ok & ok \\
\hline Elbasvir/grazoprevir (Zepatier () & $1 \mathrm{~b}, 4$ & ok & Tacro $(1,5 \mathrm{x})$ & Contra-indicated & Slight Siro/evero & ok \\
\hline
\end{tabular}

Choice of DAA treatment and potential interference with immunosuppressive regimens

For both strategies, a pangenotypic regimen is generally to be the treatment of choice (sofosbuvir/ velpatasvir; glecaprevir/pibrentasvir) with a duration ranging from 8 to 12 weeks. One could eventually opt for elbasvir/grazoprevir for known genotype $1 \mathrm{~b}$ or genotype 4 infection. Similar to non-transplant HCV-infected patients, response to treatment should be monitored with PCR testing at least at the end of the treatment course and 12 weeks after treatment cessation. To date, there is no evidence that transplanted patients respond differently to DDA treatment than the non-transplanted population (56, 90-92). Non-infection or sustained virological response can reasonably be ascertained with a negative HCV-PCR test 12 weeks after completion of treatment. In many cases, this coincides with approximately the 6-month post-transplant time point and implies that further testing for $\mathrm{HCV}$ infection beyond this time point should be avoided unless there is a high clinical suspicion of infection. Some precaution is to be applied when DAAs are used in the transplanted patients and more frequent monitoring of blood levels of immunosuppressive medication might be required. Table 2 summarizes the most frequently encountered drug-to- drug interactions. More information can be found on the following website, www.hep-druginteractions.org/checker.

\section{Conclusion and future perspectives}

The new highly efficacious and well-tolerated DAA regimens make the use of $\mathrm{HCV}-\mathrm{NAT}+$ organs for $\mathrm{HCV}$ negative recipients a true option in organ transplantation. There are many potential benefits including an increase of the donor pool, decreased waiting times and decreased mortality on the waiting list. In addition, the procedure might be lifesaving in severe conditions. Although shortterm outcomes seem to be encouraging with the use of rapid DDA treatment after transplantation, there are still many open questions especially concerning the optimal treatment strategy to be applied as well as medium and long-term outcomes. To date, HCV-NAT+ organs for $\mathrm{HCV}$-negative recipients should only be used in the context of standardized procedures and protocols with prospective recording of graft and patient outcomes. This is of particular importance for countries with low HCVprevalence in the general population such as Belgium $(0.22 \%)$, which will further decrease with general treatment uptake. In those countries, $\mathrm{HCV}+$ organs will likely be retrieved primarily from a subpopulation with high risk behavior reported to present a higher prevalence of $\mathrm{HCV}$-infection compared to the general population tab $(93,94)$. Finally, rigorous and comprehensive HCVrelated education programs must be developed and subsequently offered to potential recipients of HCVpositive organs. It is also mandatory to obtain written informed consent prior to inscription on the waiting list.

BeLIAC consider DAAs as an opportunity to the transplant community to solve the HCV problem in donors but there is ongoing debate of how to make the best use of this landmark medical breakthrough for our patients awaiting a liver transplant (95). Many questions remain to be answered and we clearly need to unit forces to make this new challenge a success story.

\section{B. Normothermic isolated liver perfusion as organ selection tool}

The availability of suitable liver grafts for transplantation is a major hurdle in LT. Worldwide, liver transplant services struggle with the difficult problem of scarcity. Indeed, at current, LT depends upon the availability of donor organs, either from a living or a deceased donor, and the demand far exceeds the availability of suitable liver grafts. This is reflected by waitlist mortality which, in Eurotransplant, averages between $15 \%$ to $20 \%(96)$. Because of this scarcity, access to waiting lists are strictly regulated and priority on the waiting list requires the difficult balancing of urgency, equity, and utility with physicians relying on imperfect tools to make these difficult decisions. The increasingly older donor population that suffers from more and more co-morbidities will further pressure the availability of suitable grafts, while expansion of indications for LT as discussed above, with conditions such as acute alcoholic hepatitis and isolated hepatic colorectal metastases, shown to be beneficial to patients, will increase the pressure on waiting lists $(6,97,98)$.

Against this background, it is striking to observe that despite the implementation of different strategies to 
increase the number of liver transplants, there are still a considerable number of donor liver grafts that are not transplanted. Data from the USA, UK, and Eurotransplant show that around $20 \%$ to $33 \%$ of deceased donor livers offered for transplantation are not transplanted while 15 to $20 \%$ of candidates die on the waiting list (99). Clearly some livers declined for transplantation are rightfully turned down because of contra-indications for transplantation such as cancer and infectious diseases. However, a substantial number of them would almost certainly provide a favourable risk-benefit ratio to some waitlisted patients.

Although the reasons for livers to be discarded for transplantation are numerous (e.g. age, steatosis, ischemic damage, bad flush out, ...), they all boil down to the lack of tools that allow to assess the future function of the liver graft offered for transplantation (99). Fear of primary non-function and ischemic cholangiopathy are major reasons to turn down a liver offered for transplantation.

Risk assessment of a particular (suboptimal) liver offer is difficult with our current forecasting and predictive tools. All our current forecasting tools for patient survival have major shortcomings and lack predictive accuracy and they do not predict liver function in the recipient. The assessment of liver viability/quality before transplantation has traditionally involved pre-retrieval review of the donor circumstances and biochemistry and imaging, followed by visual appraisal of the liver and sometimes a liver biopsy. This has been further refined by prognostic models which give an estimation of the risk of graft function/failure based on multivariate analysis of large donor datasets, so called risk indices (including donor/recipient age, sex, race, height, cause of death, from a brain dead or circulatory death donor, cold ischemic time,...) (99-102). While such tools aim to reduce uncertainty about the suitability of a liver for transplantation, they all lack predictive accuracy (e.g; $c$-statistics $\sim 0.70$ ), limiting their usefulness in routine practice.

New methods to assess the viability and quality of the donor liver graft before transplantation are needed. Normothermic isolated liver perfusion (NILP), also called normothermic machine perfusion of the liver, is being developed as a platform to preserve, assess and resuscitate liver grafts $(98,103)$.

NILP can be thought of as a heart-lung machine for the isolated liver. During NILP the liver is perfused with a red blood cell-based solution (or a solution with an oxygen carrier) warmed up to body temperature with continuous provision of oxygen and nutrients. The bile duct is cannulated to collect bile.

In a randomised controlled trial, NILP used to preserve the liver graft during transport from the donor to the recipient hospital, results in reduced ischemia-reperfusion injury as measured by peak AST posttransplant compared to livers that are classically cold-stored (104). In addition, the chance to develop early allograft dysfunction was reduced by $72 \%$ and this despite longer donor warm ischemia times and longer preservation time with NILP reaching up to 24 hours (104). Furthermore, the use of NILP reduced liver discard rates by $50 \%$, making more livers available for successful transplantation (104). Recent clinical studies have also shown that a short period of NILP immediately before transplantation has similar results (105).

NILP is now used by some centres to assess liver transplant function before transplantation and an increasing number of livers initially considered unsuitable for transplantation have been transplanted successfully after assessment by NILP $(99,106-112)$. Initial data show that lactate clearance, glucose evolution and $\mathrm{pH}$ regulation during NILP reflect hepatocyte function while bile composition ( $\mathrm{pH}$, glucose) reflects cholangiocyte viability and the development of posttransplant cholangiopathy in particular $(99,111)$. These parameters have been used by several transplant teams to assess liver that were initially turned down for transplantation and transplant those that adhered to viability criteria to be transplanted successfully $(107-111,113,114)$.

This growing experience clearly shows that a large pool of suitable livers currently remains undetected. The challenge now lies in the clear establishment and validation of viability criteria that reliably predict shortand long-term outcomes after transplantation of a liver assessed by NILP.

\section{Conclusion}

New challenges in LT are emerging. BeLIAC aims to discuss these innovations and to open new perspectives in the field of transplantation in Belgium.

With the advances in transplant oncology, LT is considered as a tool in the race for cure. Beside the oncological indications, the good results of transplantation in acute alcoholic hepatitis open the debate of transplantation despite the absence of abstinence. The Belgian transplant centres and the BeLIAC participate in several trials to help answering the remaining questions in these newer indications. However, resources remain scarce. BeLIAC therefore discuss possibilities to increase the donor pool such as transplanting organs form HCVpositive donors or using NILP to recover grafts that would not have been suitable for transplantation initially.

\section{Conflict of interest}

The authors declare no conflict of interest nor financial support for the present work.

\section{References}

1. MATHURIN P., MORENO C., SAMUEL D., DUMORTIER J., SALLERON J., DURAND F. et al. Early liver transplantation for severe alcoholic hepatitis, N. Engl. J. Med. 2011, 365 : 1790-1800.

2. SAPISOCHIN G., HIBI T., GHOBRIAL M., MAN K. The ILTS Consensus Conference on Transplant Oncology: Setting the Stage, Transplantation 2020, 104. 
3. DUVOUX C., ROUdOT-THORAVAL F., DECAENS T., PESSIONE F., BADRAN H., PIARDI T. et al. Liver transplantation for hepatocellular carcinoma: a model including $\alpha$-fetoprotein improves the performance of Milan criteria, Gastroenterology 2012, 143 : 986-994.e983 ; quiz e914-985.

4. SCHIELKE A., MEURISSE N., LAMPROYE A., HONORÉ P., DELWAIDE J., HUSTINX R. et al. Selection criteria for liver transplantation in patients with hepatocellular carcinoma. Eastern and western experiences, and perspectives for the future, Acta Gastroenterol. Belg. 2019, 82 : 314-318.

5. MAJNO P., MENTHA G., GIOSTRA E., TERRAZ S., RUBBIA-BRANDT L., BERNEY T. et al. Treatment of hepatocellular carcinoma at the dawn of the third millennium : liver transplantation and its alternatives, Acta Gastroenterol. Belg. 2004, 67 : 206-222.

6. HAGNESS M., FOSS A., LINE P. D., SCHOLZ T., JORGENSEN P. F., FOSBY B. et al. Liver Transplantation for Nonresectable Liver Metastases From Colorectal Cancer, Annals of Surgery 2013, $257:$ 800-806.

7. HIBI T., RELA M., EASON J. D., LINE P.-D., FUNG J., SAKAMOTO S. et al. Liver Transplantation for Colorectal and Neuroendocrine Liver Metastases and Hepatoblastoma. Working Group Report From the ILTS Transplant Oncology Consensus Conference, Transplantation 2020, 104

8. DERUYTTER E., VAN STEENKISTE C., TRÉPO E., GEERTS A., VAN VLIERBERGHE H., BERREVOET F. et al. Liver transplantation for alcoholic liver disease: a retrospective analysis of recidivism, survival and risk factors predisposing to alcohol relapse, Acta Gastroenterol. Belg. 2013, $76: 282-290$.

9. DOM G., FRANCQUE S., MICHIELSEN P. Risk for relapse of alcohol use after liver transplantation for alcoholic liver disease: a review and proposal of a set of risk assessment criteria, Acta Gastroenterol. Belg. 2010, 73 : 247-251.

10. EASL Clinical Practice Guidelines: Management of alcohol-related liver disease, J. Hepatol. 2018, 69: 154-181.

11. CRABB D. W., BATALLER R., CHALASANI N. P., KAMATH P. S., LUCEY M., MATHURIN P. et al. Standard Definitions and Common Data Elements for Clinical Trials in Patients With Alcoholic Hepatitis: Recommendation From the NIAAAAlcoholic Hepatitis Consortia, Gastroenterology 2016, 150 : 785-790.

12. LOUVET A., THURSZ M. R., KIM D. J., LABREUCHE J., ATKINSON S. R., SIDHU S. S. et al. Corticosteroids Reduce Risk of Death Within 28 Days for Patients With Severe Alcoholic Hepatitis, Compared With Pentoxifylline or Placebo-a Meta-analysis of Individual Data From Controlled Trials, Gastroenterology 2018, 155 : 458-468.e458.

13. LOUVET A., NAVEAU S., ABDELNOUR M., RAMOND M. J., DIAZ E., FARTOUX L. et al. The Lille model: a new tool for therapeutic strategy in patients with severe alcoholic hepatitis treated with steroids, Hepatology 2007, $45:$ : 1348-1354.

14. Consensus conference : Indications for Liver Transplantation, January 19 and 20, 2005, Lyon-Palais Des Congrès: text of recommendations (long version), Liver Transpl. 2006, 12 : 998-1011.

15. MAROT A., DUBOIS M., TRÉPO E., MORENO C., DELTENRE P. Liver transplantation for alcoholic hepatitis : A systematic review with metaanalysis, PLoS One 2018, 13 : e 0190823.

16. LEE B. P., MEHTA N., PLATT L., GURAKAR A., RICE J. P., LUCEY M. R. et al. Outcomes of Early Liver Transplantation for Patients With Severe Alcoholic Hepatitis, Gastroenterology 2018, 155 : 422-430.e421.

17. ALEXANDRE LOUVET J. L., CHRISTOPHE MORENO, CLAIRE VANLEMMENS, ROMAIN MOIRAND, et al. Early liver transplantation for severe alcoholic hepatitis not reponding to medical treatment : results of the French-Belgian prospective study quicktrans., Hepatology 2020, 72 : 4A-5A

18. DONCKIER V., LUCIDI V., GUSTOT T., MORENO C. Ethical considerations regarding early liver transplantation in patients with severe alcoholic hepatitis not responding to medical therapy, J. Hepatol. 2014, 60 : 866-871.

19. MAROT A., MORENO C., DELTENRE P. Liver transplant for alcoholic hepatitis: a current clinical overview, Expert Rev. Gastroenterol. Hepatol. 2020, $14:$ :591-600.

20. DEGROOTE H., CALLEBOUT E., IESARI S., DEKERVEL J., SCHREIBER J., PIRENNE J. et al. Extended criteria for liver transplantation in hepatocellular carcinoma. A retrospective, multicentric validation study in Belgium, Surg. Oncol. 2020, 33 : 231-238.

21. ADLER M., DE PAUW F., VEREERSTRAETEN P., FANCELlO A., LERUT J., STARKEL P. et al. Outcome of patients with hepatocellular carcinoma listed for liver transplantation within the Eurotransplant allocation system, Liver Transpl. 2008, $14:$ 526-533.

22. MAZZAFERRO V., LLOVET J. M., MICELI R., BHOORI S., SCHIAVO M., MARIANI L. et al. Predicting survival after liver transplantation in patients with hepatocellular carcinoma beyond the Milan criteria: a retrospective, exploratory analysis, Lancet Oncol. 2009, $10: 35-43$.

23. MAZZAFERRO V., REGALIA E., DOCI R., ANDREOLA S., PULVIRENTI A., BOZZETTI F. et al. Liver transplantation for the treatment of small hepatocellular carcinomas in patients with cirrhosis, N. Engl. J. Med. 1996, $334:$ : 693-699.

24. AMADO V., RODRÍGUEZ-PERÁLVAREZ M., FERRÍN G., DE LA MATA M. Selecting patients with hepatocellular carcinoma for liver transplantation: incorporating tumor biology criteria, J. Hepatocell. Carcinoma 2019, 6 : $1-10$.

25. KORNBERG A., WITT U., SCHERNHAMMER M., KORNBERG J., CEYHAN G. O., MUELLER K. et al. Combining (18)F-FDG positron emission tomography with Up-to-seven criteria for selecting suitable liver transplant patients with advanced hepatocellular carcinoma, Sci. Rep. 2017, 7 : 14176.

26. DETRY O., GOVAERTS L., DEROOVER A., VANDERMEULEN M., MEURISSE N., MALENGA S. et al. Prognostic value of (18)F-FDG PET/ CT in liver transplantation for hepatocarcinoma, World J. Gastroenterol. 2015, 21 : 3049-3054.

27. KORNBERG A., FREESMEYER M., BÄRTHEL E., JANDT K., KATENKAMP K., STEENBECK J. et al. 18F-FDG-uptake of hepatocellular carcinoma on PET predicts microvascular tumor invasion in liver transplant patients, Am. J. Transplant. 2009, $9:$ 592-600.

28. CRONIN K. A., LAKE A. J., SCOTT S., SHERMAN R. L., NOONE A. M., HOWLADER N. et al. Annual Report to the Nation on the Status of Cancer, part I: National cancer statistics, Cancer 2018, $124:$ 2785-2800.

29. SIEGEL R. L., MILLER K. D., JEMAL A. Colorectal Cancer Mortality Rates in Adults Aged 20 to 54 Years in the United States, 1970-2014, Jama 2017, $318: 572-574$.

30. STEELE G., JR., RAVIKUMAR T. S. Resection of hepatic metastases from colorectal cancer. Biologic perspective, Ann. Surg. 1989, 210 : 127-138.

31. BLUMGART L. H., ALLISON D. J. Resection and embolization in the management of secondary hepatic tumors, World J. Surg. 1982, 6 : 32-45.

32. ADAM R., DELVART V., PASCAL G., VALEANU A., CASTAING D., AZOULAY D. et al. Rescue surgery for unresectable colorectal liver metastases downstaged by chemotherapy: a model to predict long-term survival, Ann.Surg. 2004, 240 : 644-657 ; discussion 657-648.

33. KHATRI V. P., PETRELLI N. J., BELGHITI J. Extending the frontiers of surgical therapy for hepatic colorectal metastases: is there a limit?, J. Clin. Oncol. 2005, 23 : 8490-8499.

34. PENN I. Hepatic transplantation for primary and metastatic cancers of the liver, Surgery 1991, 110 : 726-734; discussion 734-725.

35. MÜHLBACHER F., HUK I., STEININGER R., GNANT M., GÖTZINGER P., WAMSER P. et al. Is orthotopic liver transplantation a feasible treatment for secondary cancer of the liver?, Transplant Proc. 1991, 23 : 1567-1568.

36. WASAN H. S., GIBBS P., SHARMA N. K., TAIEB J., HEINEMANN V., RICKE J. et al. First-line selective internal radiotherapy plus chemotherapy versus chemotherapy alone in patients with liver metastases from colorectal cancer (FOXFIRE, SIRFLOX, and FOXFIRE-Global) : a combined analysis of three multicentre, randomised, phase 3 trials, Lancet Oncol. 2017, 18 : 1159-1171.

37. HOTI E., ADAM R. Liver transplantation for primary and metastatic liver cancers, Transpl. Int. 2008, $21:$ 1107-1117.

38. DUELAND S., GUREN T. K., HAGNESS M., GLIMELIUS B., LINE P. D., PFEIFFER P. et al. Chemotherapy or liver transplantation for nonresectable liver metastases from colorectal cancer?, Ann. Surg. 2015, 261 : 956-960.

39. DUELAND S., FOSS A., SOLHEIM J. M., HAGNESS M., LINE P. D. Survival following liver transplantation for liver-only colorectal metastases compared with hepatocellular carcinoma, Br. J. Surg. 2018, 105 : 736-742.

40. DUELAND S., GRUT H., SYVERSVEEN T., HAGNESS M., LINE P. D. Selection criteria related to long-term survival following liver transplantation for colorectal liver metastasis, Am. J. Transplant. 2020, $20: 530-537$.

41. DUELAND S., SYVERSVEEN T., SOLHEIM J. M., SOLBERG S., GRUT H., BJØRNBETH B. A. et al. Survival Following Liver Transplantation for Patients With Nonresectable Liver-only Colorectal Metastases, Ann. Surg. 2020, $271: 212-218$.

42. NADALIN S., KÖNIGSRAINER A., CAPOBIANCO I., SETTMACHER U., RAUCHFUSS F. Auxiliary living donor liver transplantation combined with two-stage hepatectomy for unresectable colorectal liver metastases, Curr. Opin. Organ. Transplant. 2019, 24 : 651-658.

43. SHAH A. P., CAMERON A., SINGH P., FRANK A. M., FENKEL J. M. Successful treatment of donor-derived hepatitis $C$ viral infection in three transplant recipients from a donor at increased risk for bloodborne pathogens, Transpl. Infect. Dis. 2017, 19.

44. LINE P. D., HAGNESS M., BERSTAD A. E., FOSS A., DUELAND S. A Novel Concept for Partial Liver Transplantation in Nonresectable Colorectal Liver Metastases : The RAPID Concept, Ann. Surg. 2015, 262 : e5-9.

45. KÖNIGSRAINER A., TEMPLIN S., CAPOBIANCO I., KÖNIGSRAINER I., BITZER M., ZENDER L. et al. Paradigm Shift in the Management of Irresectable Colorectal Liver Metastases: Living Donor Auxiliary Partial Orthotopic Liver Transplantation in Combination With Two-stage Hepatectomy (LD-RAPID), Ann. Surg. 2019, $270:$ 327-332. 
46. RAUCHFUSS F., NADALIN S., KÖNIGSRAINER A., SETTMACHER U. Living donor liver transplantation with two-stage hepatectomy for patients with isolated, irresectable colorectal liver-the LIVER-T(W)O-HEAL study, World J. Surg. Oncol. 2019, $17: 11$.

47. COUBEAU L., IESARI S., CICCARELLI O., BONACCORSI-RIANI E., DAHLQVIST G., REDING R. Two-Stage Recipient Hepatectomy and Left Liver Transplantation to Minimize Risks in Adult-to-Adult Living Donor Liver Transplantation: New Concepts, Liver Transpl. 2020, 26 : 450-455.

48. GUREVICH M., GUY-VITERBO V., JANSSEN M., STEPHENNE X., SMETS F., SOKAL E. et al. Living Donor Liver Transplantation in Children: Surgical and Immunological Results in 250 Recipients at Université Catholique de Louvain, Ann. Surg. 2015, 262 : 1141-1149.

49. GRUT H., SOlBERG S., SEIERSTAD T., REVHEIM M. E., EGGE T. S., LARSEN S. G. et al. Growth rates of pulmonary metastases after liver transplantation for unresectable colorectal liver metastases, Br. J. Surg. 2018, $105: 295-301$

50. WANG X. W., ZHANG Y. J. Targeting mTOR network in colorectal cancer therapy, World J. Gastroenterol. 2014, 20 : 4178-4188.

51. JØRGENSEN K. K., LINDSTRÖM L., CVANCAROVA M., CASTEDAL M., FRIMAN S., SCHRUMPF E. et al. Colorectal neoplasia in patients with primary sclerosing cholangitis undergoing liver transplantation: a Nordic multicenter study, Scand. J. Gastroenterol. 2012, 47 : 1021-1029.

52. MERCHEA A., SHAHJEHAN F., CROOME K. P., COCHUYT J. J., LI Z., COLIBASEANU D. T. et al. Colorectal Cancer Characteristics and Outcomes after Solid Organ Transplantation, J. Oncol. 2019, 2019 : 5796108.

53. LINE P. D., DUELAND S. Liver transplantation for secondary liver tumours: The difficult balance between survival and recurrence, J. Hepatol. 2020, 73 1557-1562.

54. CRISMALE J. F., AHMAD J. Expanding the donor pool: Hepatitis C, hepatitis B and human immunodeficiency virus-positive donors in liver transplantation, World J. Gastroenterol. 2019, 25 : 6799-6812.

55. FABRIZI F., MARTIN P., DIXIT V., BUNNAPRADIST S., DULAI G. Hepatitis $\mathrm{C}$ virus antibody status and survival after renal transplantation: meta-analysis of observational studies, Am. J. Transplant. 2005, 5 : 14521461.

56. MATHURIN P., MOUQUET C., POYNARD T., SYLLA C., BENALIA H., FRETZ C. et al. Impact of hepatitis B and C virus on kidney transplantation outcome, Hepatology 1999, $29:$ 257-263.

57. SISE M. E., CHUTE D. F., GUSTAFSON J. L., WOJCIECHOWSKI D., ELIAS N., CHUNG R. T. et al. Transplantation of hepatitis C virus infected kidneys into hepatitis C virus uninfected recipients, Hemodial. Int. 2018, 22 Suppl 1 : S71-s80.

58. NORTHUP P. G., ARGO C. K., NGUYEN D. T., MCBRIDE M. A., KUMER S. C., SCHMITT T. M. et al. Liver allografts from hepatitis C positive donors can offer good outcomes in hepatitis $\mathrm{C}$ positive recipients: a US National Transplant Registry analysis, Transpl. Int. 2010, 23 : 1038-1044.

59. STEPANOVA M., SAYINER M., DE AVILA L., YOUNOSZAI Z., RACILA A., YOUNOSSI Z. M. Long-term outcomes of liver transplantation in patients with hepatitis $\mathrm{C}$ infection are not affected by HCV positivity of a donor, BMC Gastroenterol. 2016, $16: 137$.

60. COTTER T. G., ARONSOHN A., REDDY K. G., CHARLTON M. Liver Transplantation of HCV-Viremic Donors into HCV-Negative Recipients in the USA: Increasing Frequency with Profound Geographic Variation, Transplantation 2020.

61. COTTER T. G., PAUl S., SANDIKÇI B., COURI T., BODZIN A. S., LITTLE E. C. et al. Increasing Utilization and Excellent Initial Outcomes Following Liver Transplant of Hepatitis C Virus (HCV)-Viremic Donors Into HCV-Negative Recipients: Outcomes Following Liver Transplant of HCVViremic Donors, Hepatology 2019, 69 : 2381-2395.

62. THULUVATH P. J., BRUNO D. A., ALUKAL J., SATAPATHY S. K., THULUVATH A. J., ZHANG T. Use of HCV-Positive Livers in HCVNegative Recipients, Am. J. Gastroenterol. 2020, 115 : 1045-1054.

63. POLANCO N. P., GOLDBERG D. Transplanting Livers From "HCVPositive" Donors To HCV-Negative Recipients: Increased Experience But Many Unanswered Questions, Am. J. Gastroenterol. 2020, 115 : 1022-1023.

64. FENG S., LAI J. C. Expanded criteria donors, Clin. Liver Dis. 2014, 18 : $633-$ 649.

65. LUCKETT K., KAISER T. E., BARI K., SAFDAR K., SCHOECH M. R., APEWOKIN S. et al. Use of Hepatitis C Virus Antibody-Positive Donor Livers in Hepatitis C Nonviremic Liver Transplant Recipients, J. Am. Coll. Surg. 2019, $228: 560-567$.

66. BARI K., LUCKETT K., KAISER T., DIWAN T., CUFFY M., SCHOECH M. R. et al. Hepatitis $C$ transmission from seropositive, nonviremic donors to non-hepatitis C liver transplant recipients, Hepatology 2018, 67 : 1673-1682.

67. DE VERA M. E., VOLK M. L., NCUBE Z., BLAIS S., ROBINSON M., ALLEN N. et al. Transplantation of hepatitis C virus (HCV) antibody positive, nucleic acid test negative donor kidneys to $\mathrm{HCV}$ negative patients frequently results in seroconversion but not $\mathrm{HCV}$ viremia, Am. J. Transplant. $2018,18: 2451-2456$.

68. PATEL S. R., MADAN S., SAEED O., SIMS D. B., SHIN J. J., NUCCI C. et al. Cardiac transplantation from non-viremic hepatitis C donors, J. Heart Lung Transplant. 2018, 37 : 1254-1260.

69. LEVITSKY J., FORMICA R. N., BLOOM R. D., CHARLTON M., CURRY M., FRIEDEWALD J. et al. The American Society of Transplantation Consensus Conference on the Use of Hepatitis C Viremic Donors in Solid Organ Transplantation, Am. J. Transplant. 2017, $17:$ 2790-2802.

70. SEEM D. L., LEE I., UMSCHEID C. A., KUEHNERT M. J. PHS guideline for reducing human immunodeficiency virus, hepatitis B virus, and hepatitis C virus transmission through organ transplantation, Public Health Rep. 2013, $128: 247-343$

71. AGBIM U., CSEPREKAL O., YAZAWA M., TALWAR M., BALARAMAN V., BHALLA A. et al. Factors associated with hepatitis C antibody seroconversion after transplantation of kidneys from hepatitis $\mathrm{C}$ infected donors to hepatitis C naïve recipients, Ren. Fail 2020, 42 : 767-775.

72. PRAKASH K., RAMIREZ-SANCHEZ C., RAMIREZ S. I., LOGAN C., LAW N., MEKEEL K. et al. Post-transplant survey to assess patient experiences with donor-derived HCV infection, Transpl. Infect. Dis. 2020, e13402

73. CAMPOS-VARELA I., AGUDELO E. Z., SARKAR M., ROBERTS J. P., TERRAULT N. A. Use of a hepatitis C virus (HCV) RNA-positive donor in a treated HCV RNA-negative liver transplant recipient, Transpl. Infect. Dis. 2018, 20.

74. KWONG A. J., WALL A., MELCHER M., WANG U., AHMED A. SUBRAMANIAN A. et al. Liver transplantation for hepatitis C virus (HCV) non-viremic recipients with HCV viremic donors, Am. J. Transplant. 2019, 19 : 1380-1387.

75. BETHEA E., ARVIND A., GUSTAFSON J., ANDERSSON K., PRATT D., BHAN I. et al. Immediate administration of antiviral therapy after transplantation of hepatitis $\mathrm{C}$-infected livers into uninfected recipients: Implications for therapeutic planning, Am. J. Transplant. 2020, 20 : 16191628.

76. BOHORQUEZ H., BUGEAUD E., BZOWEJ N., SCHEUERMANN J., HAND J., BRUCE D. et al. Liver Transplantation Using Hepatitis C VirusViremic Donors Into Hepatitis C Virus-Aviremic Recipients as Standard of Care, Liver Transpl. 2020

77. SAID A., WEISS M., VARHELYI A., FARAGO R., BALLWEG C., RICE J. et al. Utilization of hepatitis $\mathrm{C}$ viremic donors for liver transplant recipients without hepatitis C. A veterans transplant center report, Transpl. Infect. Dis. 2020, e13466.

78. CRISMALE J. F., KHALID M., BHANSALI A., DE BOCCARDO G., KHAIM R., FLORMAN S. S. et al. Liver, simultaneous liver-kidney, and kidney transplantation from hepatitis C-positive donors in hepatitis C-negative recipients : A single-center study, Clin. Transplant. 2020, 34 : e13761.

79. KAPILA N., MENON K. V. N., AL-KHALLOUFI K., VANATTA J. M., MURGAS C., REINO D. et al. Hepatitis C Virus NAT-Positive Solid Organ Allografts Transplanted Into Hepatitis C Virus-Negative Recipients: A RealWorld Experience, Hepatology 2020, 72 : 32-41.

80. FRANCO A., MORESO F., MERINO E., SANCHO A., KANTER J., GIMENO A. et al. Renal transplantation from seropositive hepatitis $\mathrm{C}$ virus donors to seronegative recipients in Spain : a prospective study, Transpl. Int. 2019, $32: 710-716$.

81. DURAND C. M., BOWRING M. G., BROWN D. M., CHATTERGOON M A., MASSACCESI G., BAIR N. et al. Direct-Acting Antiviral Prophylaxis in Kidney Transplantation From Hepatitis C Virus-Infected Donors to Noninfected Recipients : An Open-Label Nonrandomized Trial, Ann. Intern. Med. 2018, $168: 533-540$.

82. REESE P. P., ABT P. L., BLUMBERG E. A., VAN DEERLIN V. M., BLOOM R. D., POTLURI V. S. et al. Twelve-Month Outcomes After Transplant of Hepatitis C-Infected Kidneys Into Uninfected Recipients: A Single-Group Trial, Ann. Intern. Med. 2018, 169 : 273-281.

83. WETTERSTEN N., TRAN H., MEKEEL K., PRETORIUS V., ADLER E., ASLAM S. Successful heart-kidney transplantation from a Hepatitis C viremic donor to negative recipient: One year of follow-up, Transpl. Infect. Dis. 2019, 21 : e13002.

84. MCLEAN R. C., REESE P. P., ACKER M., ATLURI P., BERMUDEZ C., GOLDBERG L. R. et al. Transplanting hepatitis $\mathrm{C}$ virus-infected hearts into uninfected recipients: A single-arm trial, Am. J. Transplant. 2019, 19 : 2533 2542.

85. BETHEA E. D., GAJ K., GUSTAFSON J. L., AXTELL A., LEBEIS T., SCHOENIKE M. et al. Pre-emptive pangenotypic direct acting antiviral therapy in donor $\mathrm{HCV}$-positive to recipient $\mathrm{HCV}$-negative heart transplantation: an open-label study, Lancet Gastroenterol. Hepatol. 2019, 4 : 771-780. 
86. SCHLENDORF K. H., ZALAWADIYA S., SHAH A. S., WIGGER M., CHUNG C. Y., SMITH S. et al. Early outcomes using hepatitis C-positive donors for cardiac transplantation in the era of effective direct-acting antiviral therapies, J. Heart Lung Transplant. 2018, 37 : 763-769.

87. ZHU Y., SHUDO Y., LEE R., WOO Y. J. Heart Transplant Using Hepatitis C-Seropositive and Viremic Organs in Seronegative Recipients, Ann. Transplant. 2020, 25 : e922723.

88. SMITH D. E., CHEN S., FARGNOLI A., LEWIS T., GALLOWAY A. C., KON Z. N. et al. Impact of Early Initiation of Direct-Acting Antiviral Therapy in Thoracic Organ Transplantation From Hepatitis C Virus Positive Donors, Semin. Thorac. Cardiovasc. Surg. 2020.

89. CYPEL M., FELD J. J., GALASSO M., PINTO RIBEIRO R. V., MARKS N., KUCZYNSKI M. et al. Prevention of viral transmission during lung transplantation with hepatitis $\mathrm{C}$-viraemic donors: an open-label, singlecentre, pilot trial, Lancet Respir. Med. 2020, $8:$ 192-201.

90. MANSOUR M., HILL L., KERR J. Safety and effectiveness of direct acting antivirals for treatment of hepatitis $\mathrm{C}$ virus in patients with solid organ transplantation, Transpl. Infect. Dis. 2018, 20 : e12972.

91. COHEN E., LIAPAKIS A. Pharmacokinetics and important drug-drug interactions to remember when treating advanced chronic kidney disease patients with hepatitis C direct acting anti-viral therapy, Semin. Dial. 2019, 32 : 141-151.

92. LIU J., MA B., CAO W., LI M., BRAMER W. M., PEPPELENBOSCH M. P. et al. Direct-acting antiviral agents for liver transplant recipients with recurrent genotype 1 hepatitis $\mathrm{C}$ virus infection: Systematic review and meta-analysis, Transpl. Infect. Dis. 2019, 21 : e13047.

93. LITZROTH A., SUIN V., WYNDHAM-THOMAS C., QUOILIN S MUYLDERMANS G., VANWOLLEGHEM T. et al. Low hepatitis C prevalence in Belgium: implications for treatment reimbursement and scale up, BMC Public Health 2019, 19 : 39

94. MATHEÏ C., BOURGEOIS S., BLACH S., BRIXKO C., MULKAY J. P., RAZAVI H. et al. Mitigating the burden of hepatitis $\mathrm{C}$ virus among people who inject drugs in Belgium, Acta Gastroenterol. Belg. 2016, 79 : 227-232.

95. BURTON J. R., JR., TERRAULT N. A., GOLDBERG D. S., BLOOM R. D., GILROY R., HEIMBACH J. K. et al. Liver and Kidney Recipient Selection of Hepatitis C Virus Viremic Donors: Meeting Consensus Report From the 2019 Controversies in Transplantation, Transplantation 2020, 104 : 476481.

96. JOCHMANS I., VAN ROSMALEN M., PIRENNE J., SAMUEL U. Adult Liver Allocation in Eurotransplant, Transplantation 2017, 101 : 1542-1550.

97. LEE B. P., CHEN P. H., HAUGEN C., HERNAEZ R., GURAKAR A., PHILOSOPHE B. et al. Three-year Results of a Pilot Program in Early Liver Transplantation for Severe Alcoholic Hepatitis, Ann. Surg. 2017, 265 : 20-29.

98. JOCHMANS I., AKHTAR M. Z., NASRALLA D., KOCABAYOGLU P. BOFFA C., KAISAR M. et al. Past, Present, and Future of Dynamic Kidney and Liver Preservation and Resuscitation, Am. J. Transplant. 2016, 16 : 2545-2555.

99. WATSON C. J. E., JOCHMANS I. From "Gut Feeling" to Objectivity: Machine Preservation of the Liver as a Tool to Assess Organ Viability, Curn Transplant. Rep. 2018, $5:$ : 72-81.

100. BRAAT A. E., BLOK J. J., PUTTER H., ADAM R., BURROUGHS A. K., RAHMEL A. O. et al. The Eurotransplant donor risk index in liver transplantation: ET-DRI, Am. J. Transplant. 2012, 12 : 2789-2796.
101. FENG S., GOODRICH N. P., BRAGG-GRESHAM J. L., DYKSTRA D M., PUNCH J. D., DEBROY M. A. et al. Characteristics associated with liver graft failure: the concept of a donor risk index, Am. J. Transplant. 2006, $6: 783-790$.

102. WATSON C. J., JOHNSON R. J., BIRCH R., COLLETT D., BRADLEY J. A. A simplified donor risk index for predicting outcome after deceased donor kidney transplantation, Transplantation 2012, 93 : 314-318.

103. MAIONE F., GILBO N., LAZZARO S., FRIEND P., CAMUSSI G., ROMAGNOLI R. et al. Porcine Isolated Liver Perfusion for the Study of Ischemia Reperfusion Injury : A Systematic Review, Transplantation 2018, 102 : 1039-1049.

104. NASRALlA D., COUSSIOS C. C., MERGENTAL H., AKHTAR M. Z., BUTLER A. J., CERESA C. D. L. et al. A randomized trial of normothermic preservation in liver transplantation, Nature 2018, 557 : 50-56.

105. CERESA C., NASRALLA D., WATSON C., BUTLER A., CRICK K., IMBER C. et al. The effect of normothermic machine perfusion after cold storage in liver transplantation : a multicentre prospective clinical trial, Transplantation 2018, $102: 27-27$.

106. MERGENTAL H., PERERA M. T., LAING R. W., MUIESAN P., ISAAC J. R., SMITH A. et al. Transplantation of Declined Liver Allografts Following Normothermic Ex-Situ Evaluation, Am. J. Transplant. 2016, 16 : 32353245 .

107. PERERA T., MERGENTAL H., STEPHENSON B., ROLL G. R., CILLIERS H., LIANG R. et al. First human liver transplantation using a marginal allograft resuscitated by normothermic machine perfusion, Liver Transpl. 2016, 22 : 120-124.

108. WATSON C. J. E., KOSMOLIAPTSIS V., RANDLE L. V., GIMSON A. E., BRAIS R., KLINCK J. R. et al. Normothermic Perfusion in the Assessment and Preservation of Declined Livers Before Transplantation: Hyperoxia and Vasoplegia-Important Lessons From the First 12 Cases, Transplantation 2017, 101 : 1084-1098.

109. WATSON C. J., KOSMOLIAPTSIS V., RANDLE L. V., RUSSELL N. K., GRIFFITHS W. J., DAVIES S. et al. Preimplant Normothermic Liver Perfusion of a Suboptimal Liver Donated After Circulatory Death, Am. $J$. Transplan. 2016, $16:$ 353-357.

110. WATSON C. J., RANDLE L. V., KOSMOLIAPTSIS V., GIBBS P., ALLISON M., BUTLER A. J. 26-hour Storage of a Declined Liver Before Successful Transplantation Using Ex Vivo Normothermic Perfusion, Ann. Surg. 2017, 265 : e1-e2.

111. WATSON C. J. E., KOSMOLIAPTSIS V., PLEY C., RANDLE L., FEAR C., CRICK K. et al. Observations on the ex situ perfusion of livers for transplantation, Am. J. Transplant. 2018, 18 : 2005-2020.

112. MERGENTAL H., LAING R. W., KIRKHAM A. J., PERERA T. P. R., BOTEON Y., ATTARD J. et al. Transplantation after Viability Testing of Discarded Livers with Normothermic Machine Perfusion (NMP): The Vittal (VIability Testing and Transplantation of Marginal Livers) Trial 90-Day Outcomes, Hepatology 2018, $68: 1 \mathrm{~A}-1 \mathrm{~A}$.

113. DE VRIES Y., MATTON A. P. M., NIJSTEN M. W. N., WERNER M. J. M., VAN DEN BERG A. P., DE BOER M. T. et al. Pretransplant sequential hypo- and normothermic machine perfusion of suboptimal livers donated after circulatory death using a hemoglobin-based oxygen carrier perfusion solution, Am. J. Transplant. 2019, 19: 1202-1211.

114. MERGENTAL H., LAING R. W., KIRKHAM A. J., PERERA M., BOTEON Y. L., ATTARD J. et al. Transplantation of discarded livers following viability testing with normothermic machine perfusion, Nat. Commun. 2020, $11: 2939$ 